\title{
PRIMARY HEADACHE DIAGNOSIS AMONG CHRONIC DAILY HEADACHE PATIENTS
}

\author{
Abouch Valenty Krymchantowski ${ }^{1}$
}

\begin{abstract}
Chronic daily headache $(C D H)$ refers to a group of non-paroxysmal daily or near-daily headaches with peculiar characteristics that are highly prevalent in populations of neurological clinics and not uncommon among non-patient populations. Most of the patients with CDH had, as primary diagnosis, episodic migraine, which, with the time, presented a progressive frequency, pattern modification and loss of specific migraine characteristics. Other CDH patients had chronic tension-type headache, new daily persistent headache and hemicrania continua, which evolved thru the time to the daily or near-daily presentation. The objective of this study was to determine the primary headache diagnosis among a population of chronic daily headache patients attending a tertiary center for headache treatment. During a 5 -year period 651 consecutive chronic daily headache patients attending a private subspecialty center were studied prospectively. The criteria adopted were those proposed by Silberstein et al (1994, revised 1996). Five hundred seventy four patients (88.1\%) had episodic migraine as primary headache before turning into daily presentation, $52(8 \%)$ had chronic tensiontype headache, $14(2.2 \%)$ had hemicrania continua and 11 patients $(1.7 \%)$ had new daily persistent headache. $\mathrm{CDH}$ is quite frequent in patients from clinic-based studies suggesting a high degree of disability. Emphasis on education of patients suffering from frequent primary headaches with regard to measures that are able to decrease suffering and disability as well as better medical education directed to more efficient ways to handle these patients are necessary to improve outcome of such a prevalent condition.
\end{abstract}

KEY WORDS: chronic daily headache, primary diagnosis, transformed migraine.

\section{Diagnóstico da cefaléia primária em pacientes com cefaléia crônica diária}

RESUMO - Cefaléias crônicas diárias (CCD) representam um grupo de cefaléias diárias ou quase diárias, não paroxísticas, com características peculiares que são altamente prevalentes em populações de clínicas neurológicas e não incomuns em populações aleatórias de não pacientes. Muitos dos pacientes com CCD apresentavam, como cefaléia primária, a migrânea episódica a qual, com o tempo, revelou freqüência progressiva, mudança de apresentação clínica e perda de características típicas. Outros pacientes tinham cefaléia do tipo tensional crônica, cefaléia persistente diária de início súbito ou hemicrania continua antes da evolução para a apresentação diária. 0 objetivo deste estudo é determinar o diagnóstico primário da cefaléia de pacientes com CCD em atendimento em um centro terciário. Durante um período de 5 anos, 651 pacientes consecutivos com CCD foram estudados prospectivamente. Os critérios de inclusão adotados foram os propostos por Silberstein e col. (1994, revisados em 1996). Entre estes, $574(88,1 \%)$ apresentavam o diagnóstico de migrânea episódica como cefaléia primária, $52(8 \%)$ o de cefaléia do tipo tensional crônica, $14(2,2 \%)$ o de hemicrania continua e $11(1,7 \%)$ pacientes o diagnóstico primário de cefaléia persistente diária de início súbito. As CCDs são bastante freqüentes em pacientes de clínicas especializadas não raro provocando alto grau de incapacidade funcional. Ênfase é dada na educação de pacientes que sofrem de cefaléias freqüentes, quanto às medidas que podem ser adotadas para minimizar o sofrimento e a incapacidade, assim como à melhor educação médica sobre como abordar estes pacientes de forma mais eficiente são necessárias para diminuir o impacto que essa freqüente condição provoca.

PALAVRAS-CHAVE: cefaléia crônica diária, diagnóstico primário, migrânea transformada.

Chronic daily headache $(\mathrm{CDH})$ refers to a group of non paroxysmal headaches, including those associated with overuse of symptomatic medications, that presents on a daily or near-daily basis, with a duration greater than 4 hours a day and lasting longer than 6 months $\mathrm{s}^{1-3}$. It's prevalence in the general population varies from 0,5 to $6 \%$, affecting more women than men and representing

\footnotetext{
1Department of Neurology Universidade Federal Fluminense, Headache Center of Rio and Instituto de Neurologia Deolindo Couto of Universidade Federal do Rio de Janeiro (UFRJ), Rio de Janeiro RJ - Brasil.
}

Received 30 August 2002, received in final form 13 January 2003. Accepted 21 January 2003.

Dr. Abouch Valenty Krymchantowski - Headache Center of Rio - www.dordecabeca.com.br - Avenida das Américas 1155/1608 22631-000 Rio de Janeiro - Brasil. FAX: 552124913657. E-mail: abouchkrym@globo.com. 
$40 \%$ or more of all patients attending specialized headache clinics ${ }^{4,5}$.

Most of the patients with $\mathrm{CDH}$ had, as primary diagnosis, episodic migraine which, with the time, presented a progressive frequency, pattern modification and loss of specific migraine characteristics, therefore presenting a daily or near-daily headache, with mixed clinical features of migraine and tensiontype headache ${ }^{3-5}$. This daily or near-daily headache, evolving from episodic migraine and presenting clinical features of migraine and tension-type headache, has been called as transformed migraine ${ }^{4,5}$. The proposed criteria for transformed migraine were presented and revised by Silberstein et al. ${ }^{6,7}$ that also suggested that other $\mathrm{CDH}$ patients have chronic tension-type headache, new daily persistent headache and hemicrania continua as primary diagnosis, which evolved thru the time to the daily or near-daily presentation.

The objective of this study was to determine the primary headache diagnosis among a population of chronic daily headache patients attending a tertiary center for headache treatment.

\section{METHOD}

During the period from January 97 to January 2002, 651 consecutive chronic daily headache patients attending a private subspecialty headache center were studied prospectively. The inclusion criteria were the presence of daily or near-daily (at least 4 days per week) headache, lasting (if untreated) at least 4 hours per day, for longer than 6 months. The exclusion criteria were the identification of any secondary cause for the presented headache. Regular concomitant use of any medication other than oral contraceptives, symptomatic drugs for acute treatment of headache, traditional preventive headache medications and drugs used for the treatment of peptic diseases were also considered exclusion criteria. Once the patients were included, the criteria used to accomplish the diagnosis of the primary headaches were those proposed by Silberstein et al. in $1994^{6}$ and revised, with regard to transformed migraine, in 19967. The criteria for classifying the subgroups of migraine were those published by the International Headache Society in $1988^{8}$.

All patients were evaluated by the author in initial consultations not shorter than one hour and, in addition, ans- wered a questionnaire with details concerning the headache initiation, evolution and characteristics, as well as factors involved in its worsening, progression and their habits of symptomatic and regular medication consumption. All the patients included in this study had normal physical and neurological examinations.

\section{RESULTS}

Five hundred thirty nine women and 112 men, ages 17 to 84 years (mean 46 ) were included. Among them, $574(88.1 \%)$ had episodic migraine as primary headache before turning into daily presentation according to the criteria proposed by Silberstein et al. ${ }^{6,7}$. Five hundred seventeen patients fulfilled the International Headache Society criteria ${ }^{8}$ for migraine without aura (90\%), 41 (7.2\%) for migraine without aura and with aura and $14(2.8 \%)$ for migraine with aura. Fifty-two patients (8\%) had chronic tensiontype headache, 14 patients $(2.2 \%)$ had hemicrania continua and 11 patients (1.7\%) had new daily persistent headache (Table 1).

\section{DISCUSSION}

Chronic daily headache is a common problem in tertiary centers and among specialists that dedicate to headache patients ${ }^{4}$. Even though there is evidence that most of $\mathrm{CDH}$ patients evolved from migraine, some of the patients may have evolved from chronic tension-type headache, may have started with an already daily headache or may present a continuous unilateral head pain known as hemicrania continua ${ }^{6,9}$. This is exactly what we observed in our study. Most of the patients $(88,1 \%)$ presented episodic migraine as primary headache diagnosis, which evolved thru the time, to a daily or near-daily presentation. Even though not all of the migraineurs of our sample had migraine without aura before the pattern transformation, most of them had this type of migraine as their episodic headache as emphasized by Mathew ${ }^{4,5}$ when analyzing his patients before the transformation to a different migraine presentation.

Mathew and his colleagues ${ }^{5}$ studied 630 daily or near-daily headache patients and found 487 (77\%) who evolved from migraine (introducing the term transformed migraine). Manzoni et al., initially in

Table 1. Primary headache of the patients from the present study.

\begin{tabular}{ccccc}
\hline $\begin{array}{c}\text { Total cases } \\
(\mathrm{n})\end{array}$ & $\begin{array}{c}\text { Migraine } \\
\mathrm{n}(\%)\end{array}$ & $\begin{array}{c}\text { TTH } \\
\mathrm{n}(\%)\end{array}$ & $\begin{array}{c}\text { NDPH } \\
\mathrm{n}(\%)\end{array}$ & $\begin{array}{c}\text { Hemicrania continua } \\
\mathrm{n}(\%)\end{array}$ \\
\hline 651 & $574(88.1)$ & $52(8 \%)$ & $11(1.7 \%)$ & $14(2.2)$ \\
$(537 \mathrm{~F}, 112 \mathrm{M})$ & & & & \\
\hline
\end{tabular}


Table 2. Relative incidence of subtypes of chronic daily headache in the headache clinic population.

\begin{tabular}{lccccc}
\hline & $\begin{array}{c}\text { Total } \\
\text { cases } \\
(\mathrm{n})\end{array}$ & $\begin{array}{c}\text { Male } \\
(\%)\end{array}$ & $\begin{array}{c}\text { Female } \\
(\%)\end{array}$ & $\begin{array}{c}\text { Evolved from } \\
\text { migraine } \\
\mathrm{n}(\%)\end{array}$ & $\begin{array}{c}\text { Evolved } \\
\text { from tension- } \\
\text { type headache } \\
\mathrm{n}(\%)\end{array}$ \\
\hline Mathew et al. (1987) & 630 & 26 & 74 & $487(77 \%)$ & $143(23 \%)$ \\
Manzoni et al. (1987) & 250 & 24 & 76 & $178(71.2)$ & $72(28.8 \%)$ \\
Manzoni et al. (1991) & 58 & 11 & 89 & $44(75)$ & $14(25 \%)$ \\
Solomon et al. (1992)* & 100 & 28 & 72 & $34(34)^{* *}$ & $66(66)^{* * *}$ \\
Krymchantowski (2001) & 300 & 68 & 232 & $271(90.3 \%)$ & $29(9.7 \%)$ \\
\hline
\end{tabular}

*Reported that the majority evolved from migraine; pointed out the need for separate classification for CDH. ** Met IHS criteria for migraine; ${ }^{* * *}$ Met IHS criteria for chronic tension-type headache

1987 and subsequently in $1991^{10,11}$, also found most of their patients with $\mathrm{CDH}$ having transformed from episodic migraine. The first studied group of patients had 250 subjects and revealed, as primary headache diagnosis, migraine in $178(71,2 \%)$ and tension-type headache in $72(28,8 \%)$ patients. In the second study of Manzoni and his group, it was demonstrated that $44(75 \%)$ among $58 \mathrm{CDH}$ patients evolved from episodic migraine, whereas 14 (25\%) presented tensiontype headache as primary diagnosis. Solomon et al. in $1992^{\circ}$ also recognized $\mathrm{CDH}$ and mentioned that the majority of their 100 cases transformed from episodic migraine, although actual percentages were not given. In private practice headache centers the percentages may be even higher. Krymchantowski and Moreira encountered 90,3\% their $\mathrm{CDH}$ patients presenting with the primary headache diagnosis of migraine $^{12}$ (Table 2).

In addition, we encountered just the minority of our patients $(11,9 \%)$ with other forms of primary
Table 3. Specific categories of chronic daily headache according to the criteria proposed by Silberstein et al. ${ }^{10}$.

Daily or near-daily headche lasting $>4 \mathrm{~h} /$ day for $>15$ days/month

1.8 Transformed migraine (TM)

1.8.1 With overuse of SM*

1.8.2 Without overuse of SM

2.2 Chronic tension-type headache (CTTH)

2.2.1 With overuse of SM

2.2.2 Without overuse of SM

4.7 New daily persistent headache (NDPH)

4.7.1 With overuse of SM

4.7.2 Without overuse of SM

4.8 Hemicrania Continua (HC)

4.8.1 With overuse of SM

4.8.2 Without overuse of SM

*SM, symptomatic medications. Obs: The numbers for CTTH refer to its current position in the international headache classification. The other headache categories indicate the proposed criteria to include and position these headache subtypes in the mentioned classification.

Table 4. Relative incidence of subtypes of chronic daily headache in population samples.

\begin{tabular}{lccccc}
\hline & $\begin{array}{c}\text { Total } \\
\text { number } \\
\text { of cases } \\
(\mathrm{n})\end{array}$ & $\begin{array}{c}\text { Male } \\
(\%)\end{array}$ & $\begin{array}{c}\text { Female } \\
(\%)\end{array}$ & $\begin{array}{c}\text { Evolved from } \\
\text { migraine } \\
\mathrm{n}(\%)\end{array}$ & $\begin{array}{c}\text { Evolved } \\
\text { from tension- } \\
\text { type headache } \\
\mathrm{n}(\%)\end{array}$ \\
\hline Scher et al. (1998) & $\begin{array}{c}547^{*} \\
(4.1 \%)\end{array}$ & $2.8 \%$ & $5.0 \%$ & $164(30 \%)$ & $289(52.8 \%)$ \\
Castillo et al. (1999) & $\begin{array}{c}89 * * \\
(4.7 \%)\end{array}$ & $1.0 \%$ & $8.7 \%$ & $45(50.6 \%)$ & $42(47.2 \%)$ \\
Lu et al. (2001) & $\begin{array}{c}108 * * * \\
(3.2 \%)\end{array}$ & $1.9 \%$ & $4.3 \%$ & $59(55 \%)$ & $47(44 \%)$ \\
\hline
\end{tabular}

*Ninety four patients were unclassified; **Two patients received the diagnosis of $\mathrm{NDPH}$; ***Two patients had other types of CDH 
headache before turning into a daily headache. As demonstrated by Mathew et al. ${ }^{5}$ and Solomon et al. ${ }^{9}$, around $90 \%$ of the $\mathrm{CDH}$ patients evolved from migraine and less than $10 \%$ from CTTC, NDPH and the hemicrania continua. The main problem with the characterization of patients presenting with primary daily or near-daily headache and, consequently with its allocation in the current classification, is the fact that these headaches do not meet the IHS criteria for migraine, or for chronic tension-type headache or even for headaches induced by chronic use of substances, despite of the fact that it is common, among these patients, to overuse symptomatic medications ${ }^{8,9}$.

However, although $\mathrm{CDH}$ patients are difficult to classify, it was suggested that they might be subdivided into specific categories of primary headaches, which evolved into the daily presentation, frequently with gradual loss of typical characteristics ${ }^{6}$ (Table 3 ).

We decided to adopt these proposed criteria in order to classify our patients and allocate them within the suggested categories of $\mathrm{CDH}$ due to the fact that these criteria were presented and proposed based in clinical practice findings.

In population studies however, the status is different. While the majority of the patients from clinic population studies present with $\mathrm{CDH}$ due to transformed migraine, CDH affects 3,2 to $4,3 \%$ of subjects from random population series ${ }^{1,13,14}$. Chronic tensiontype headache and TM are similarly prevalent reaching percentages around $50 \%$ for each of the groups. Scher et al. ${ }^{14}$ observed in a series of 13343 individuals from Maryland, representative of the American population, the overall prevalence of $\mathrm{CDH}$ in $4,1 \%$. Among them, more than half ( $52 \%$ female, $56 \%$ male) had CTTH and 33\% had transformed migraine (the other $15 \%$ couldn't be classified). Castillo et al. ${ }^{1}$ obtained similar numbers. In a population of 1883 subjects, 4,7\% (89 patients) fulfilled the proposed criteria for CDH being 47,2\% (42 patients) with CTTH and 50,6\% (45 patients) with TM. Lu et al. ${ }^{13}$ found lower percentages. Among 3377 subjects, $108(3,2 \%)$ fulfilled the proposed criteria for $\mathrm{CDH}$, with a higher prevalence in women $(4,3 \%)$ than in men $(1,9 \%)$. TM was the most common sub- type (55\%) followed by CTTH (44\%). These numbers are far different from those observed in the present study, which used subjects from a specialized headache clinic, therefore corroborating what was already suggested by Castillo et al. ${ }^{1}$ and Scher et al. ${ }^{14}$ (Table 4).

Chronic daily headache is not uncommon in the general population but it is quite frequent in patients from clinic-based studies suggesting a high degree of disability. Among these patients, migraineurs who evolved from an episodic form of headache to a daily or near-daily one, represent the majority of sufferers. Emphasis on education of patients suffering from frequent primary headaches with regard to measures that are able to decrease suffering and disability as well as better medical education directed to more efficient ways to handle these patients are necessary to improve outcome of such a prevalent condition.

\section{REFERENCES}

1. Castillo J, Muñoz P, Guitera V, Pascual J. Epidemiology of chronic daily headache in the general population. Headache 1999;39:190-196

2. Mathew NT. Neurobiology of transformed migraine. Introduction and clinical presentation. Proceedings of the $40^{\text {th }}$ Annual Scientific Meeting of the American Association for the Study of Headache, 1998:13-20.

3. Krymchantowski AV, Barbosa JSS, Lorenzatto WS, Adriano MV, Cherm CJ. Clinical features of transformed migraine. Cephalalgia 1999;19:336-337.

4. Mathew NT. Transformed migraine. Cephalalgia 1993;13(Suppl 12):78-83.

5. Mathew NT, Reuveni U, Perez F. Transformed or evolutive migraine. Headache 1987;27:102-106.

6. Silberstein SD, Lipton RB, Solomon S, Mathew NT. Classification of daily and near-daily headaches: proposed revisions to the IHS criteria. Headache 1994;34:1-7.

7. Silberstein SD, Lipton RB, Sliwinski M. Classification of daily and neardaily headaches: field trial of revised IHS criteria. Neurology 1996;47:871-875.

8. Headache Classification Committee of the International Headache Society. Classification and diagnostic criteria for headache disorders, cranial neuralgias and facial pain. Cephalalgia 1988;8(Suppl 7):1-96.

9. Solomon S, Lipton R, Newman L. Evaluation of chronic daily headache: comparison to criteria for chronic tension-type headache. Cephalalgia 1992;12:365-368.

10. Manzoni GC, Micieli G, Granella F, Martignoni E, Malferrari G, Nappi G. Daily chronic headache: classification and clinical features: observation on 250 patients. Cephalalgia 1987;7(Suppl 6):169-170.

11. Manzoni GC, Sandrini , Zanferrari C, Verri AP, Granella F, Nappi G. Clinical features of daily chronic headache and its different subtypes. Cephalalgia 1991;11(Suppl 11):292-293.

12. Krymchantowski AV, Moreira PF. Clinical presentation of transformed migraine: possible differences among male and female patients. Cephalalgia 2001;21:558-566.

13. Lu SR, Fuh JL, Chen WT, Juang KD, Wang SJ. Chronic daily headache in Taipei, Taiwan: prevalence, follow-up and outcome predictors. Cephalalgia 2001;21:980-986.

14. Scher AI, Stewart WF, Liberman J, Lipton RB. Prevalence of frequent headache in a population sample. Headache 1988;38:497-506. 